\title{
O JOVEM E SUA VISÃO DE IMORTALIDADE
}

\author{
IMMORTALITY FEELING AMONG ADOLESCENTS
}

Jael de Paula Guimarães

Médica Hebiatra. Ambulatório de Adolescentes. Secretaria Municipal de Saúde de Ribeirão Preto Correspondência: Rua Amador Bueno, 237. 14010-070 - Ribeirão Preto, SP.

Guimarães JP. O jovem e sua visão de imortalidade. Medicina ( Ribeirão Preto\} 2005; 38 (1): $42-44$.

Resumo: O texto comenta os pensamentos onipotentes que o adolescente tem diante da morte. Para isso, tece comentários sobre a "síndrome da adolescência normal", de acordo com as teorias de Aníbal Ponce desenvolvidas por Maurício Knobel e Arminda Aberastury.

Descritores: Adolescente. Morte. Síndrome da Adolescência Normal.

No presente trabalho discutiremos a visão que tem o adolescente a respeito da morte e sua percepção de imortalidade. Iniciaremos comentando as experiências vividas pelo jovem e as dificuldades por ele enfrentadas ao passar da infância para a idade adulta. Alguns pesquisadores já se preocuparam em descrever as diferentes transformações que ao mesmo tempo perturbam o jovem e o preparam para experiências posteriores da vida, as quais passaremos a comentar em seguida.

Aníbal Ponce ${ }^{1}$, psicanalista argentino que brilhantemente escreveu a respeito das vivências emocionais dos adolescentes, iniciou os estudos desta fase da vida comentando ser o jovem aquele indivíduo em permanente conflito, controvertido em suas idéias e repetidamente envolvido em atitudes paradoxais. A causa desta "confusão" toda foi posteriormente chamada de "síndrome da adolescência normal". Os principais aspectos desta síndrome serão apresentados neste artigo.

Antes de descrever as características desta síndrome, é preciso dizer que seus autores afirmaram que os transtornos psicopatológicos observados nada mais são que a expressão magnificada, distorcida, do comportamento humano normal, e que isto ocorre na evolução de todo adolescente. Esses comportamentos variam de indivíduo para indivíduo, de cultura para cultura ou de um grupo social para outro. Os limites que definem o início e o fim desta fase também variam muito. O professor Mauricio Knobel ${ }^{2}$ comentou haver "uma situação que obriga o sujeito a reformular os conceitos que tem a respeito de si mesmo e que o levam a abandonar sua auto-imagem infantil e a projetar-se no futuro de sua vida adulta". Dr. Knobel e outra psicanalista argentina, a doutora Arminda Aberastury $^{2}$, são os pesquisadores responsáveis pela caracterização da citada síndrome. Eles prosseguem dizendo que para atingir a estabilização da personalidade há que se passar por certo grau de conduta patológica, que eles consideraram "inerentes a esta etapa da vida”. Anna Freud (citada pelo Dr. Knobel), afirmou "que é muito difícil assinalar o limite entre o normal e o patológico na adolescência", acrescentando que "seria anormal a presença de um equilíbrio estável durante o processo adolescente".

No entender desses pesquisadores, é preciso haver o conflito, a crise para que o jovem cresça, amadureça, adquira identidade adulta. A noção que o 
jovem tem da possibilidade de morrer ou de se deparar com a perda de alguém significativo o bastante para fazê-lo sofrer de modo intenso, faz com que ele viva o dia-a-dia como alguém quase que invulnerável, inatingível pelas coisas que afligem os adultos e aqueles que estão distantes do seu cotidiano.

A síndrome da adolescência normal decorre de vivências na maioria das vezes total ou parcialmente inconscientes. Esses eventos íntimos assinalados por Aníbal Ponce ${ }^{1,}$ e mais detalhados e elaborados por Arminda Aberastury ${ }^{2}$, são:

1- luto pelo corpo infantil perdido

2- luto pela identidade e papel infantil perdidos

3- luto pelos pais da infância, também perdidos.

\section{1- O LUTO PELO CORPO INFANTIL}

O jovem assiste passivamente às suas mudanças e se vê impotente frente à realidade concreta. Esta impotência faz com que ele desloque sua rebeldia para a esfera do pensar. Ele passa a fazer um manejo onipotente das idéias frente ao fracasso da realidade. Isto fica bem evidente nas idéias de reforma do mundo, tanto sociais quanto políticas, religiosidade por vezes intensa. Há o pensamento de que nada $o$ atinge. Esta onipotência faz com que o adolescente acredite na sua imortalidade ou na daqueles que lhes são caros (negação da morte).

\section{2- O LUTO PELA IDENTIDADE E PELO PAPEL INFANTIL PERDIDOS}

Ao mesmo tempo que o adolescente não pode manter os papéis infantis, ele não pode assumir a independência plena do adulto. Existe uma "fase do fracasso de personificação". Ele então delega ao grupo parte de seus atributos, e aos pais boa parte de suas responsabilidades e obrigações. Verificamos, aí, a irresponsabilidade típica desta fase.

O jovem vive um processo característico de comprovação e experimentação de objetos do mundo real e da fantasia que se confundem. Isto permite despersonificar os seres humanos, tratando-os como objetos de suas satisfações. As assim chamadas relações objetais têm caráter muito intenso, embora sejam frágeis e fugazes. As manifestações migram das crises passionais (idolatria à personalidades da mídia, colegas da escola, namorado(a), lendas do rock e do futebol, etc) a indiferenças absolutas, muitas vezes cruéis, com pessoas e animais.
A negação do luto associada à identificação projetiva (fato do indivíduo visualizar em terceiros características que são na verdade pertencentes a ele mesmo) levam-no a ter pensamentos com particularidades do grupo ao qual pertence ("turmas"). Amor e ódio, culpa e reparação são sentimentos intensamente vividos e rapidamente eliminados.

\section{3- LUTO PELA PERDA DOS PAIS DA INFÂN- CIA}

As contradições existentes nas atitudes e pensamentos causam incongruência entre os pais internalizados e os pais reais. Essas contradições aparecem quando um jovem paga os refrigerantes consumidos pela "turma" na lanchonete (potente perante terceiros) com o dinheiro que ele pediu aos pais (dependente da família). Esta alternância de sentimentos, ser dependente ou independente, capaz ou incapaz, levam o adolescente a interromper a comunicação com os pais externos, reais: refugia-se no quarto, faz meditação, análise, escreve em diário íntimo, projeta a imagem paterna idealizada em professores, amigos próximos, atletas, políticos, etc. A solidão periódica é ativamente procurada pelo adolescente porque facilita a conexão com os objetos internos e a sua substituição, o que enriquece mais o seu ego.

Com relação à noção de tempo, o adolescente apresenta contradições entre o imediatismo e a capacidade de postergar indefinidamente qualquer ação. Ao elaborar os lutos ele se torna capaz de localizar o corpo e papel infantis no passado, aceitar o transcurso do tempo e reconhecer o conceito de morte como irreversível e natural.

Aníbal Ponce ${ }^{1}$ considerava o descobrimento do tempo e da morte como um tormento tão perturbador quanto o sexo e o desenvolvimento da sexualidade adulta. Dizia que a percepção interna de que os momentos vividos se sucedem inexoravelmente constitui um bombardeio de sentimentos dolorosos. A noção de que a vida passa num fluir incessante deixam-no diante de um sentimento de inutilidade de todo o seu esforço para crescer e amadurecer. Seu medo de envelhecer e morrer turvam seus sonhos, seu ideal de independência e, se não tiver forças que o prendam à vida, ele passa a ser perseguido por forte sentimento de desesperança, que vez ou outra culminam com o suicídio. Ocorre uma convivência angustiante com a solidão e a finitude da vida, que fragiliza o adolescente, o qual necessita de muita compreensão e apoio. Se 
está doente, a explicação dos fenômenos feita pelo médico representa um consolo; se tem pensamentos místicos, a religião o conforta. O jovem pode lançar mão da defesa psíquica, que o faz retomar pensamentos e sentimentos de poder total ante a degeneração e a morte.

Guimarães JP. Immortality feeling among adolescents. Medicina ( Ribeirão Preto) 2005; 38 (1): $42-44$.

Abstract: The text discusses the adolescent omnipotent vision regarding death. Based on Anibal Ponce's theories, which were developed by Maurício Knobel and Arminda Aberastury, it analyzes some aspects of the "normal adolescent syndrome".

Keywords: Adolescence. Death. Normal Adolescent Syndrome.

\section{REFERÊNCIAS BIBLIOGRÁFICAS}

1 - Ponce A. Psicología de la adolescência. $2^{\underline{a}}$ ed. México DF:Union Tipográfica Editorial Hispano-Americana; 1938 (Reimpresión de 1960).

2 - Aberastury A, Knobel M. Adolescência normal: um enfoque psicanalítico. $10^{\text {th }}$ ed. Porto Alegre: Artes Médicas; 1992. 